\title{
Against spectatorial utopianism
}

\author{
Robert Rosenberger ${ }^{1}$
}

Received: 23 May 2021 / Accepted: 20 July 2021

(c) The Author(s), under exclusive licence to Springer-Verlag London Ltd., part of Springer Nature 2021

A recent trend in the rhetoric of climate deniers (i.e., those unconcerned about global warming) is the argument that while climate change may actually be happening, and while it may even be manmade, there is no need to do anything because future technological advances will surely solve the problem. ${ }^{1}$ That is, where climate denialism has traditionally disputed the fact that dangerous climate change is occurring, this new form instead merely denies that anything needs to be done about it. The character of these two lines argumentation is different: where traditional climate deniers dispute the science on climate change, the new trend instead relies on a utopian enthusiasm about the future of science and technology. However, the practical effects of these arguments are the same: they both advocate against addressing climate change today.

Philosophers of technology routinely express concerns about utopian thinking regarding technology. For example, Donna Haraway conveys her impatience with a common view that she summarizes as:

a comic faith in technofixes, whether secular or religious: technology will somehow come to the rescue of its naughty but clever children, or what amounts to the same thing, God will come to the rescue of his disobedient but ever hopeful children $(2016,3)$.

Or as Michel Puech writes, "futuristic speculation is not innocent. It can be considered a voluntary fictional distraction from the ordinary, from the needs and from the resources of present reality" $(2016,43)$. Here, I want to identify, label, and criticize one specific, and I think pervasive, form of utopian thinking on technology, one that can discourage active solutions to contemporary problems, and which can be used to justify inaction on the assumption that somehow in the future somebody will develop a technical solution.

Robert Rosenberger

robert.rosenberger@pubpolicy.gatech.edu

1 Georgia Institute of Technology, Atlanta, USA
To call out this form of utopian argumentation, let us borrow a notion from the American pragmatist philosophical tradition. Figures such as John Dewey and Richard Rorty use the label "spectatorial" to refer to philosophies that they allege merely observe the world, rather than act positively upon it. Used in this fashion, "spectatorship" is a pejorative term that connotes an attitude of docility, non-interference, and passivity. For example, Rorty criticizes what he takes to be the dominant form of leftism in American universities that he claims is a "spectatorial, disgusted, mocking Left rather than a Left which dreams of achieving our country" $(1998,35)$. Without weighing in on his critique of academia, his point is to call out a trend of disengagement and inaction, and to push for a Leftist alternative that is activist and engaged.

Following Rorty, I propose that the term spectatorial utopianism be used to point to a specific form of argumentation, one that I claim should always be regarded with suspicion. A technological utopian argument is spectatorial when it both (1) urges for inaction, and (2) does so on the basis of a broad and general expectation of future progress. A spectatorial utopian argues against a concrete proposal for immediate specific action on a problem by appealing to a general theory that technological advance will continue in a way that will address the problem by itself. My contention is that this kind of argument should be recognized for what it is: a call against active problem solving based on contentious assumptions about the nature of technology. ${ }^{2}$ It is important to identify and criticize this kind of argument because on its surface it can appear concrete and engaged since it is ostensibly

\footnotetext{
${ }^{1}$ Paradigmatic examples of this form of utopian climate denialismthat at once acknowledges that climate change is occurring but at the same time denies that anything needs to be done on the expectation of future technological development-can be found in US politics, and in particular in recent Republican opposition to proposed Green New Deal legislation (e.g., Wheeling 2019).

2 Of course other broad and general philosophical accounts of technology could also be used as justification for spectatorial inaction, such as a dystopian view (that might see all action as hopeless anyway), or an instrumental view (that might see technology to be inherently neutral and thus above criticism). But those forms of potential spectatorial argumentation are not the focus of this commentary.
} 
enthusiastic about science and technology. However, such arguments are often at best disengaged and philosophically suspect, and are sometimes offered disingenuously.

To clarify, the notion of spectatorial utopianism is not intended to refer to just any call for inaction based on predications about future technological developments, but only those founded on vague accounts of technological advance. For example, it is one thing if someone were to advise against concrete political action to address climate change on the basis of a specific optimistic prediction founded on concrete evidence about how particular technologies will advance and solve the problem along a particular timeline. That would not be an example of spectatorial utopianism as I have defined it here. This is because if someone were to attempt to counter this argument for inaction, then their counterargument would need to address the specifics of the claim, such as the particularities of the evidence or timetable. It is another thing if someone were to argue against concrete political action on the basis of a general story of how technological advance will probably solve our problems. It is this latter form of argumentation that I am raising cautions about here.

Of course one strategy to watch out for is an effort to obscure one's spectatorial utopian argumentation by offering just enough detail to appear concretely engaged, while actually not. For example, someone attempting to argue against addressing climate change might point toward a potential technological solution like carbon capture without offering specifics about timetables, or investment, or the challenges still to be solved with this technology. And of course spectatorial utopian arguments may be offered dishonestly. For example, if someone's main motivation is the opposition to any kind of regulation, then that person may attempt to conceal this motive by giving the appearance of concern about climate change offered in the form of spectatorial utopian argumentation.

This sort of speciousness is of course not limited to debates over the environment. For example, it can be seen in everything from those urging against regulations on distracted driving based on expectations about an upcoming future of autonomous cars, to those dismissing the need for infrastructure to assist the disabled (such as ramps, elevators, or curb cuts) on the suggestion that we will soon all have exoskeletons. (For arguments against such spectatorial utopian ploys, see: e.g., Shew 2020; Rosenberger 2021.)

One thing highlighted by all of this is the danger of progress narratives. It is good to appreciate the gains that have been made on important issues from equality, to safety, to the environment, and it is crucial to honor those who have fought for them. But there is a danger in assuming that such progress will necessarily continue, or even that it will necessarily be retained. It is good to remain open to optimism about the future. But we cannot allow lazy or poorly founded expectations to lure us into reclining positions of mere spectatorship. In addition, we cannot allow ourselves to be fooled by those with their own motivations to oppose active solutions to pressing problems, and who conceal that opposition behind a facade of sunny and disingenuous scientism.

Curmudgeon Corner Curmudgeon Corner is a short opinionated column on trends in technology, arts, science and society, commenting on issues of concern to the research community and wider society. Whilst the drive for superhuman intelligence promotes potential benefits to wider society, it also raises deep concerns of existential risk, thereby highlighting the need for an ongoing conversation between technology and society. At the core of Curmudgeon concern is the question: What is it to be human in the age of the AI machine? -Editor.

\section{Declarations}

Conflict of interest I have no declarations to make regarding funding, conflicts of interest or competing interests, data or code availability.

\section{References}

Haraway DJ (2016) Staying with the trouble: making kin in the chthulucene. Duke University Press, London

Puech M (2016) The ethics of ordinary technology. Routledge, New York

Rorty R (1998) Achieving our country: leftist thought in twentiethcentury America. Harvard University Press, Cambridge

Rosenberger, R. (2021) Stop saying that autonomous cars will eliminate driver distraction. In: Michelfelder D (Ed.). Test driving the future: autonomous vehicles and the ethics of technological change. Rowman Littlefield, forthcoming

Shew A (2020) Ableism, technoableism, and future AI. IEEE Technol Soc Mag 31(1):40-50

Wheeling K (2019) Will republican climate change proposals work? Pacific Standard, 510 2019. https://psmag.com/environment/willrepublican-climate-change-proposals-work

Publisher's Note Springer Nature remains neutral with regard to jurisdictional claims in published maps and institutional affiliations. 